\title{
Acidic Fibroblast Growth Factor Infusion Reduces Ischemic CA1 Hippocampal Damage in the Gerbil
}

\author{
V. MacMillan, K. Walton-Roche and J. Davis
}

\begin{abstract}
Occlusion of the carotid arteries for 5 minutes in the Mongolian gerbil results in selective necrosis of CAl pyramidal neurons. In the present experiments we studied whether intraventricular infusion of acidic fibroblast growth factor (aFGF) could attentuate this damage. Intraventricular infusions of bovine serum albumin (BSA-10 ng/h) or aFGF $(1,10$ or $100 \mathrm{ng} / \mathrm{h})$ were started 2 days prior to 5 minutes of bilateral carotid occlusion and continued for 5 days post-ischemia. The brains were perfused and fixed at 5 days post-ischemia and histological assessment of CAI damage was made. Animals receiving intraventricular infusions of 10 or $100 \mathrm{ng} / \mathrm{h} \mathrm{aFGF}$ showed a significant reduction of CAI neuronal damage in comparison to no treatment ischemic controls (no treatment $-8 \pm 1 ; \mathrm{aFGF} 10 \mathrm{ng} / \mathrm{h}-147 \pm$ 28; aFGF $100 \mathrm{ng} / \mathrm{h}-168 \pm 35$ cells/mm CA1; $\mathrm{P}<0.05$ for both aFGF groups). The results indicate that aFGF infusion can attenuate the severity of ischemic neuronal necrosis in the gerbil hippocampus.
\end{abstract}

RÉSUMÉ: L'infusion du facteur de croissance acide des fibroblastes diminue le dommage ischémique aux neurones de la zone CA1 de l'hippocampe chez la gerboise. L'occlusion des carotides pendant 5 minutes chez la gerboise mongole produit une nécrose sélective des neurones pyramidaux CA l. La présente étude vise à déterminer si une infusion intraventriculaire de facteur de croissance acide des fibroblastes (aFGF) pouvait atténuer ce dommage. Des infusions intraventriculaires d'albumine sérique bovine (BSA-10 ng/h) ou d'aFGF (1, $10 \mathrm{ou} 100 \mathrm{ng} / \mathrm{h})$ ont été commencées 2 jours avant une occlusion bilatérale des carotides d'une durée de 5 minutes et continuées pendant 5 jours post-ischémie. Les cerveaux étaient perfusés et fixés au jour 5 post-ischémie et on procédait à une évaluation histologique des dommages subis par les neurones CA1. Le animaux qui recevaient des infusions intraventricularies d'aFGF à 10 ou $100 \mathrm{ng} / \mathrm{h}$ présentaient une diminution significative des dommages subis par les neurones CAl par rapport aux contrôles ischémiés mais non-traités (contrôles - $8 \pm 1$; aFGF10 ng/h $-147 \pm 28$; aFGF $100 \mathrm{ng} / \mathrm{h}-168 \pm 35$ cellules/mm CA $1 ; p<0.05$ pour les deux groupes aFGF). Ces résultats indiquent qu'une infusion d'aFGF peut atténuer la sévérité de la nécrose neuronale ischémique dans l'hippocampe de la gerboise.

Can. J. Neurol. Sci. 1993: 20:37-40

A recent study has indicated that the neurotrophic factor, fibroblast growth factor (FGF) reduces the killing of cultured hippocampal neurons by glutamate. ${ }^{\prime}$ In addition, these studies indicated that alterations of intracellular calcium may be a common factor for both the damaging actions of glutamate and the protective actions of FGF. Since increases of extracellular glutamate and intracellular calcium are proposed to be important pathogenetic factors in the process of selective neuronal damage in ischemia ${ }^{2-4}$ we investigated whether intraventricular infusions of FGF might protect vulnerable hippocampal neurons from ischemia.

\section{Materials AND Methods}

The experiments were performed on adult male Mongolian gerbils (50 - 70 g; Tumblebrook Farms, West Brookfield, MA) that were allowed free access to food and water. Two days prior to ischemia the animals were anesthetized with intraperitoneal pentobarbital $(50 \mathrm{mg} / \mathrm{kg}$ ) and an ALZET osmotic pump (model 1007D, ALZA Corp., Palo Alto, Ca), connected to a polyethylene tube, was placed in the subcutaneous tissue of the back. The free end of the polyethylene tube was tunnelled subcutaneously to the skull where it was attached to a 27 gauge needle cannula which was placed in the right lateral ventricle $0.2 \mathrm{~mm}$ posterior to the bregma, $1.2 \mathrm{~mm}$ lateral to the saggital suture and $1.7 \mathrm{~mm}$ deep). The cannula was secured to the skull by the use of cyanoacrylate glue. The osmotic pump and tube were filled with sterile artificial CSF $\left(\mathrm{NaCl} 120 \mathrm{mM} ; \mathrm{NaHCO}_{3} 25 \mathrm{mM}\right.$; $\mathrm{KCl} 3.3 \mathrm{mM} ; \mathrm{CaCl}_{2} 2.6 \mathrm{mM} ; \mathrm{NaH}_{2} \mathrm{PO}_{4} 1.23 \mathrm{mM} ; \mathrm{MgSO} 4.7 \mathrm{H}_{2} \mathrm{O}$ $1.2 \mathrm{mM}$; glucose $10 \mathrm{mM}$ ) containing either recombinant acidic fibroblast growth factor ${ }^{5}$ (aFGF; 2, 20 or $200 \mathrm{mg} / \mathrm{ml}$; gift of Dr.

From the Division of Neurology, University of Toronto, Toronto (V.M.) and the Department of Medicine (Neurology), Duke University, Durham, North Carolina (K.W-R, J.D.)

Recieved March 18, 1992. Accepted in final form July 13, 1992

Reprint requests to: Dr. V. MacMillan, Room 6366, Medical Science Building, University of Toronto, Toronto, Ontario, Canada M5S 1 A8 
M. Jaye, Rorer Biotechnology Inc., King of Prussia, PA), or bovine serum albumin (BSA; $20 \mathrm{mg} / \mathrm{ml}$; Sigma Chemical Corp., St. Louis, MO) and allowed to equilibrate in a dish of artificial $\mathrm{CSF}$ for $4 \mathrm{~h}$ prior to subcutaneous insertion. The mean pumping rate of the infusion units was $0.55 \pm 0.02 \mu \mathrm{l} / \mathrm{h}$ (data provided by ALZA Corp, Palo Alto, CA) which gave delivery rates of about 1,10 and $100 \mathrm{ng} / \mathrm{h}$ for the aFGF infused animals and of $10 \mathrm{ng} / \mathrm{h}$ for the BSA infused animals. Controls consisted of nonischemic and ischemic gerbils which received no intraventricular infusions.

Two days after placement of the osmotic pumps the animals were anesthetized with $2.5 \%$ halothane in $30 \% \mathrm{O}_{2}-70 \% \mathrm{~N}_{2} \mathrm{O}$ and the carotid arteries were surgically exposed via a midline cervical incision. Both carotid arteries were occluded with small arterial clips and the halothane-anesthetic gas mixture was discontinued. At the end of $5 \mathrm{~min}$ occlusion, the arterial clips were released, the return of carotid blood flow visually confirmed and the neck wound was closed with metal skin clips. Body temperature was monitored rectally and maintained at $37-38^{\circ} \mathrm{C}$ during the occlusion by use of a heating pad and incandescent lamp.

Five days after carotid occlusion the animals were anesthetized with i.p. pentobarbital and the brain was fixed in situ via intracardiac perfusion of $20 \mathrm{ml} 0.9 \%$ saline, followed by 250 $\mathrm{ml} 10 \%$ formaldehyde. The fixed brain was subsequently removed from the skull, placed in $10 \%$ formaldehyde and processed for paraffin sections and cresyl violet staining. ${ }^{6}$ The extent of hippocampal damage was evaluated by counting the intact neurons of the CAl region of the right hippocampus in sections taken at approximately $-1.4,-1.7$ and $-2.0 \mathrm{~mm}$ to the bregma. ${ }^{7}$ The CAI length was measured with a video program and results are expressed as cells per $1 \mathrm{~mm}$ length CAl. Differences in mean cell densities were analyzed using Wilcoxon's ranked sum test for unpaired samples with $\mathrm{p}<0.05$ being needed for statistical significance.

\section{RESULTS}

Intraventricular cannulation, infusion and ischemia were generally well tolerated by the experimental animals. Thus of a total of 26 exposed animals, 5 deaths were recorded. Three of these deaths were in the $1 \mathrm{ng} / \mathrm{h}$ aFGF group and showed the pattern of acute seizures with pulmonary edema coming on immediately after release of the carotid clips. One animal in each of the 10 and $100 \mathrm{ng} / \mathrm{h}$ group showed onset of seizures with pulmonary edema at 0.5 and $2 \mathrm{~h}$ post carotid occlusion, respectively.

The mean rectal temperature during ischemia was $37.7 \pm 0.1$, $37.3 \pm 0.2,37.0 \pm 0.2,37.4 \pm 0.1$, and $37.6 \pm 0.3^{\circ} \mathrm{C}$ for the ischemic control, $10 \mathrm{ng} / \mathrm{h} \mathrm{BSA}, 1,10$ and $100 \mathrm{ng} / \mathrm{h} \mathrm{aFGF}$ groups, respectively. Body weight of all gerbils was between 45-63 g.

Table 1 gives the values for intact CAl neurons in the various experimental groups and shows that aFGF infusion at 10 and $100 \mathrm{ng} / \mathrm{h}$ had a significant protective effect on ischemic CAl, whereas $1 \mathrm{ng} / \mathrm{h}$ was without protective effect. Examination of the CAl of the 10 and $100 \mathrm{ng} / \mathrm{h}$ groups indicated that the distribution of surviving neurons was homogenous and not localized to specific areas of the CAl (see Figure 1).

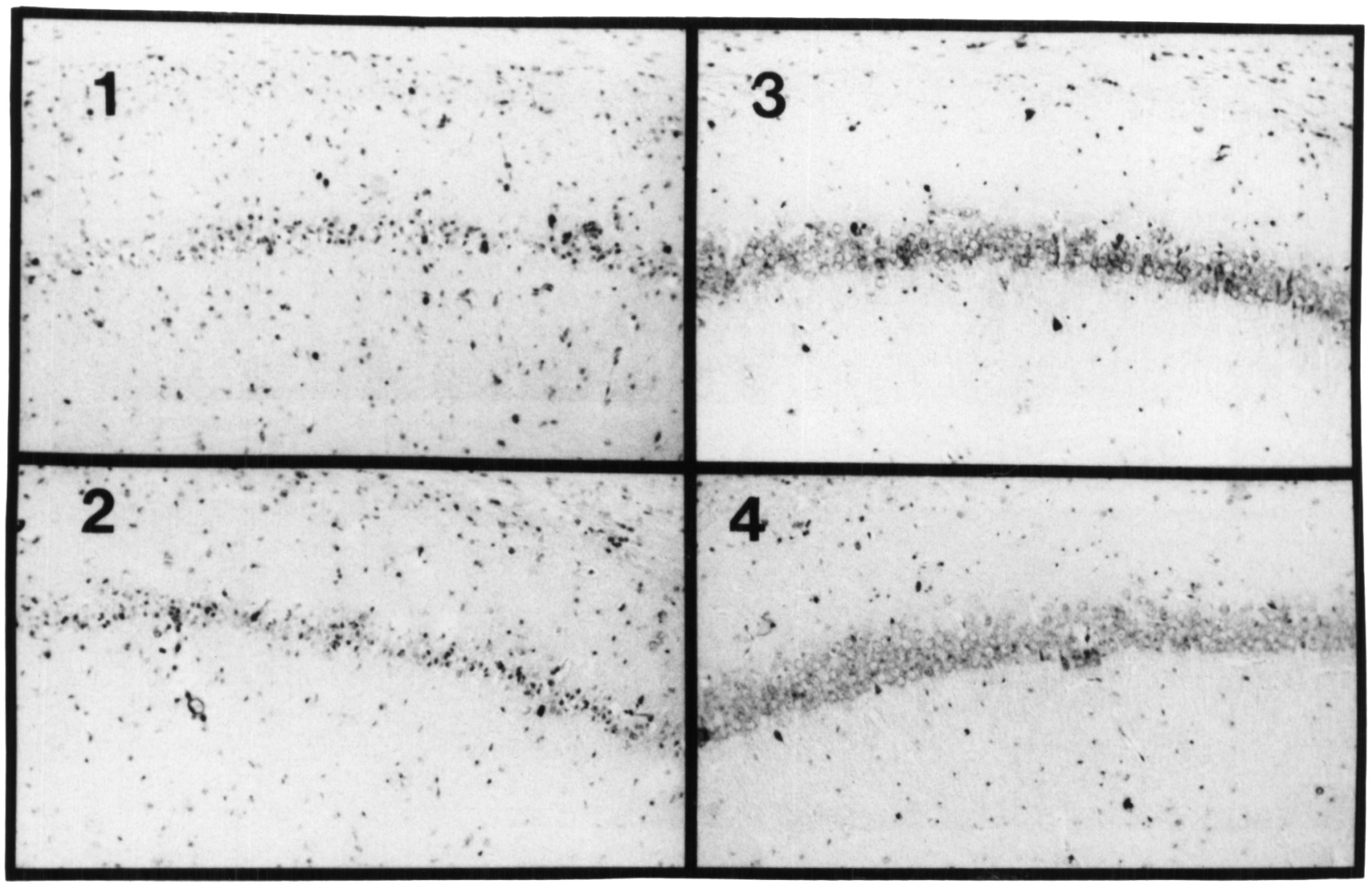

Figure 1-Microscopic appearance of CAI section of hippocampus of ischemic gerbils pretreated with intraventricular infusions of 1 . BSA $10 \mathrm{ng} / \mathrm{h}, 2$. aFGF $1 \mathrm{ng} / \mathrm{h}, 3$. aFGF $10 \mathrm{ng} / \mathrm{h}$ or 4 . aFGF $100 \mathrm{ng} / \mathrm{h}$. 
Table 1. Hippocampal CAI neuronal density in post-ischemic gerbils receiving intraventricular infusions of BSA or aFGF

\begin{tabular}{llc}
\hline \hline Experimental Group & $\mathbf{n}$ & cells/mm CAl \\
\hline 1. Non-ischemia & 8 & $197 \pm 5$ \\
2. Ischemic - no treatment & 7 & $8 \pm 1$ \\
3. Ischemic - BSA & 6 & $18+9$ \\
4. Ischemia - aFGF & & \\
$\quad 1 \mathrm{ng} / \mathrm{h}$ & 2 & $4+2$ \\
$10 \mathrm{ng} / \mathrm{h}$ & 9 & $147+28^{*}$ \\
$100 \mathrm{ng} / \mathrm{h}$ & 4 & $168+35^{*}$ \\
\hline
\end{tabular}

Values are means + SEM. $n=$ number of animals.

* $\mathrm{p}<0.05$, BSA or aFGF groups compared to no treatment ischemic control.

\section{Discussion}

The results of the present study confirm and extend observations that have indicated that neurotrophic factors have an ability to protect the central nervous system in a variety of damaging situations. These include the demonstrations that intraventricular infusions of nerve growth factor ${ }^{8-10}$ or basic FGF"l prevent death of basal forebrain cholinergic neurons after fimbria-fornix transections, that repeated intracisternal injections of basic FGF (bFGF) prevent thalamic degeneration after cortical infarction in the rat, ${ }^{12}$ and that local injection of aFGF protects the nigrostriatal dopaminergic system from the toxic effects of 1-methyl-4phenyl-1,2,3,6-tetrahydropyridine. ${ }^{13}$ In addition, Oomura et al. ${ }^{14}$ have reported in abstract format that intra-ventricular infusion of aFGF attenuates ischemic CA 1 hippocampal damage in the gerbil; an observation that directly supports the present results.

Fibroblast growth factors have been shown to have prominent mitogenic actions on fibroblasts, endothelial cells and other cells of mesenchymal origin. ${ }^{15}$ In addition, aFGF and bFGF promote survival and proliferation of CNS glial cells and a wide variety of CNS neurons in vitro. ${ }^{16} \mathrm{~A}$ possible role in the reaction to and repair of the central nervous system to injury has been proposed by Finklestein et al., ${ }^{17.18}$ who have shown prominent increases in both bFGF and aFGF in tissue surrounding focal cortical lesions.

Although the mechanism(s) by which FGF's promote the survival of neural tissue after injury is as yet unknown, the studies of Mattson et al.,' showing that pretreatment with RNA or protein synthesis inhibitors prevents the protective action of FGF in glutamate-treated hippocampal neuron cultures, indicate a possible role for FGF in the induction or regulation of a RNA or protein product which influences hippocampal neuronal survival. Since other studies have indicated that inhibition of protein synthesis reduces CAl neuronal death in ischemia, ${ }^{19}$ the in vitro data of Mattson et al.' seem to indicate that the glutamate neurotoxicity sparing action of FGF is mediated via a protein/RNA system that is different from that believed responsible for in vivo ischemic cell death. ${ }^{19}$ Further experimental studies will be needed to establish these various possibilities.

Reduction of ischemic brain temperature has been shown to be a major protective mechanism for a variety of pharmacological "anti-ischemic" agents. ${ }^{20.21}$ Although the intraventricular cannulation and process of infusion can be eliminated as causes for such temperature variations (i.e.; no protective effect in BSA infused group), it remains remotely possible that aFGF itself could act to enhance intra- or post-ischemic brain temperature reduction. In addition, the increased rate of acute post-ischemic death in the aFGF-infused animals may indicate that aFGF sensitizes the animals to the acute effects of cerebral ischemia. As described, these deaths were characterized by scizures with pulmonary edema which came on at or shortly after the termination of ischemia. The above questions remain the topics of ongoing investigation.

\section{ACKNOWLEDGEMENT}

The preparation of this study was supported by the Ontario Heart and Stroke Foundation.

\section{REFERENCES}

I. Mattson MP, Murrain M, Guthrie PB, et al. Fibroblast growth factor and glutamate: opposing roles in the generation and degeneration of hippocampal neuroarchitecture. J Neurosci 1989; 9: 3728-3740.

2. Rothman SM, and Olney JW. Glutamate and the pathophysiology of hypoxic-ischemic brain damage. Ann Neurol 1986: 19: 105111

3. Choi DW, Ionic dependence of glutamate neurotoxicity. J Neurosci 1987; 7: 369-379.

4. Choi DW, Glutamate neurotoxicity and diseases of the central nervous system. Neuron 1988; 1: 623-634.

5. Jaye $M$, Howk R, Burgess W, et al. Human endothelial cell growth factor: cloning, nucleotide sequence, and chromosomal localization. Science 1986; 233: 541-544.

6. Crain BJ, Westerkam WD, Harrison AH, et al. Selective neuronal death after transient forebrain ischemia in the Mongolian gerbil a silver impregnation study. Neurosci 1988: 27: 387-402.

7. Loskota WJ, Lomax P, Verity MA. A Stereotaxic Allas of the Mongolian Gerbil Brain. Ann Arbor Science Publishers Inc; Ann Arbor, MI, 1974.

8. Wiliams LR, Varon S, Peterson GM, et al. Continuous infusion of nerve growth factor prevents basal forebrain neuronal death after fimbria fornix transection. Proc Natl Acad Sci (USA) 1986: 83 $9231-9235$.

9. Hefti F. Nerve growth factor promotes survival of septal cholinergic neurons after fimbrial transections. J Neurosci 1986: 6: 2155 2162.

10. Kromer LF. Nerve growth factor treatment after brain injury prevents neuronal death. Science 1987; 235: 214-216.

11. Anderson KJ, Dam D, Lee S, et al. Basic fibroblast growth factor prevents death of lesioned cholinergic neurons in viro. Nature 1988; 332: 360-361.

12. Yamada K, Kinoshita A, Kohmura E, et al. Basic fibroblast growth factor prevents thalamic degeneration after cortical infarction. $J$ Cereb Blood Flow Metab 1991; 11: 472-478.

13. Date I, Notter MFD, Felten SY, et al. MPTP - treated young mice but not aging mice show partial recovery of the nigro-striatal dopaminergic system by stereotaxic injection of acidic fibroblast growth factor (aFGF). Brain Res 1990: 526: 156-160.

14. Oomura Y, Sasaki K, Muto T, et al. Physiological actions of fibroblast growth factor (FGF) in central nervous system. Soc Neurosci Abstr 1990; 16: 516

15. Gospodarowicz D. Molecular and developmental biology aspects of fibroblast growth factor. In: JE Kudlow, DH MacLennan, A Bernstein, AJ Gotlieb, eds. Biology of Growth Factors. New York: Plenum Publishing Corp, 1988: Vol 5: 23-39.

16. Walicke PA. Basic and acidic fibroblast growth factors have trophic effects on neurons from multiple CNS regions. J Neurosci 1988; 8: $2618-2627$

17. Finklestein SP, Apostolides PJ, Caday CG, et al. Increased basic fibroblast growth factor (bFGF) immunoreactivity at the site of focal brain wounds. Brain Res 1988: 460: 253-259.

18. Finklestein SF, Fanning PJ, Caday CG, et al. Increased levels of basic fibroblast growth factor (bFGF) following focal brain injury. Rest Neurol and Neurosci 1990; 1: 387-394. 
19. Shigeno T, Yamasaki Y, Kato G, et al. Reduction of delayed neuronal death by inhibition of protein synthesis. Neurosci Lett 1990; 120: 117-119.

20. Busto R, Dietrich WD, Globus M. Y-T, et al. Post-ischemic moderate hypothermia inhibits CAl hippocampal ischemic neuronal injury. Neurosci Lett 1989; 101: 299-304.
21. Buchan A and Pulsinelli WA. Hypothermia but not the N-methylD-asparate antagonist, MK-801, attenuates neuronal damage in gerbils subjected to transient global ischemia. J. Neurosci 1990; 10: $311-316$ 